\title{
Faktor Penentu Tingkat Literasi Keuangan Para Pengguna Kartu Kredit di Indonesia
}

\author{
FARAH MARGARETHA* \& SITI MAY SARI \\ Program Studi Akuntansi, Universitas Trisakti, Jalan Kyai Tapa No. 1 Grogol, Jakarta Barat, 11440, Telp (62-21) 566 3232, Indonesia. \\ *Corresponding Author, E_mail address: farahmargaretha@gmail.com
}

\begin{abstract}
The objectives of this research is to determine whether there are any significant differences between male's and female's financial literacy and whether age, educational level and income level also playing significant role in shaping credit card users' financial lieracy. Using Anova test to verify the influence of age level, educational level and income level toward financial literacy. The result of this research conclude that there are no significant differences between male's and female's financial literacy. It is verified that there are significant influences between age, education, income toward credit card users' financial literacy. Implication of this research is the share holder such as government, university, and bank more concern to make education and training to improve financial literacy of credit card user.

Keywords: Age;Education;Gender; Credit Card; Financial Literacy.
\end{abstract}

\begin{abstract}
ABSTRAK
Tujuan dari penelitian ini adalah untuk mengetahui apakah ada perbedaan yang signifikan antara laki-laki dan perempuan melek finansial dan apakah usia, tingkat pendidikan dan tingkat pendapatan juga berperan penting dalam membentuk literasi keuangan pengguna kartu kredit. Menggunakan uji Anova untuk memverifikasi pengaruh tingkat usia, tingkat pendidikan dan tingkat pendapatan terhadap melek finansial. Hasil penelitian ini menyimpulkan bahwa tidak ada perbedaan yang signifikan antara laki-laki dan perempuan terkait literasi keuangan. Hasil penelitian juga menemukan adanya pengaruh yang signifikan antara umur, pendidikan, pendapatan terhadap literasi finansial pengguna kartu kredit. Implikasi dari penelitian ini adalah pemegang saham seperti pemerintah, universitas, dan Bank perhatian lebih untuk membuat pendidikan dan pelatihan untuk meningkatkan melek finansial kartu kredit pengguna.

Kata Kunci: Umur; Pendidikan; Jenis Kelamin; Kartu Kredit; Literasi Keuangan.
\end{abstract}

\section{PENDAHULUAN}

Perkembangan perekonomian Indonesia dan perkembangan dunia perbankan yang tumbuh berkembang secara signifikan saat ini di Indonesia, menuntut dibutuhkan pengetahuan keuangan atau literasi keuangan yang baik agar setiap individu mampu mengelola sumber daya keuangannya secara efektif dan efisien guna tercapainya kesejahateraan hidup. Banyaknya variasi produk keuangan yang ditawarkan oleh perbankan untuk untuk mempermudah proses transaksi, menuntut masyarakat untuk mempunyai literasi keuangan yang baik. Dengan literasi keuangan yang baik maka masyarakat akan membuat pilihan yang tepat terkait dengan masalah keuangan yang dihadapi, baik itu berupa instrument investasi, pinjaman atau juga tabungan. Dengan literasi yang baik masyarakat mampu memanfaatkan dan mengambil keuntungan dari instrument keuangan yang ditawarkan oleh bank.

Menurut Warsono (2010) literasi ke-uangan adalah sejauhmana pengetahuan dan implementasi seseorang atau masyarakat dalam mengelola keuangan pribadinya. Tingkat literasi keuangan seseorang dapat dilihat dari sebaik apa individu 
tersebut mampu mendayagunakan sumberdaya keuangan, menentukan sumber pembelanjaan, mengelola risiko jiwa, mengelola aset yang dimilikinya, dan mempersiapkan keamanan sumber daya keuangan dimasa mendatang apabila sudah tidak bekerja.

Banyaknya orang-orang sukses terkait dengan kemampuannya dalam mengelola keuangan menjadi kajian menarik banyak kalangan untuk mempelajari literasi keuangan. Selain itu, makin ketatnya persaingan dunia perbankan yang menawarkan berbagai tingkat suku bunga tabungan dan deposito, naik turunnya tingkat suku bunga utang, dan juga pengambilan keputusan yang terkait dengan kondisi keuangan dimasa mendatang membuat masyarakat menyadari pentingnya seorang individu untuk mempelajari literasi keuangan.

Banyaknya individu yang mengalami kesulitan keuangan bukan hanya disebabkan karena pendapatan yang kecil tetapi karena kesalahan dalam mengalokasikan pendapatan. Tingkat literasi keuangan yang rendah menyebabkan kurang bijak dalam penga-lokasian pendapatan, oleh karena itu mempuyai kecerdasan literasi keuangan akan membantu dalam membuat keputusan yang tepat. Dengan literasi keuagan yang baik maka akan mampu untuk membuat skala prioritas yang baik demi terciptanya masa depan yang lebih baik lagi.

Literasi keuangan dalam bentuk pemahaman terhadap semua aspek keuangan pribadi bukan untuk mempersulit atau mengekang orang dalam menikmati hidup, tetapi justru dengan literasi keuangan, individu atau keluarga dapat menikmati hidup dengan mendayagunakan sumberdaya keuangannya dengan tepat dalam rangka mencapai tujuan keuangan pribadinya (Warsono, 2010). Selain itu, Disney dan Gathergood (2012) menemukan bahwa para peminjam atau debitur yang mempunyai tingkat literasi keuangan yang rendah (miskin literasi keuangan) lebih banyak menggunakan pinjaman yang tinggi biayanya dibandingkan mereka yang mempunyai literasi keuangan yang lebih baik. Jika memiliki literasi keuangan yang baik akan meminimalisir kemungkinan kerugian karena terlalu tinggi membayar utang bunga.

Dorongan untuk hidup konsumtif dipengaruhi oleh banyak faktor diantaranya berbagai kemudahan transaksi dan juga perkembangan dunia industri serta gaya hidup yang diterapkan, hal ini terkadang membuat seseorang tidak rasional dalam membelanjakan uangnya. Apalagi saat ini seseorang tidak harus mempunyai uang atau tabungan untuk bisa berbelanja, karena pembayaran bisa menggunakan kartu kredit. Kartu kredit menjadi alat pembayaran yang sangat popular dikalangan perkerja atau orang yang sudah memiliki penghasilan rutin. Hal ini terbukti dengan adanya data dari Bank Indonesia bahwasanya jumlah kartu kredit yang beredar per januari 2014 mencapai 15,12 juta (www.detik.com).

Berkembangnya kartu kredit yang menjadi solusi dalam bertransaksi juga dapat menimbulkan berbagai masalah, diantaranya: pengguna yang tak mampu membayar tagihannya, dan pengguna menjadi sangat konsumtif dengan tidak mempertimbangkan besarnya hutang yang ditanggung setelahnya. Oleh karena itu literasi keuangan yang baik sangat diperlukan agar para penggunaan kartu kredit sesuai dengan kebutuhan. Pengguna kartu kredit seharusnya lebih peduli lagi berapa besarnya bunga dan juga biaya administrasi yang harus ditanggung.

Banyak sekali faktor yang mem-pengaruhi tingkat literasi keuangan seseorang diantaranya: tingkat pendidikan, jurusan pendidikan, status ekonomi orang tua, usia, status pernikahan, pendapatan, dan gender. Tetapi di dalam penelitian ini hanya akan menggunakan beberapa faktor yang 
akan diteliti yaitu jenis kelamin, umur, tingkat pendidikan, dan tingkat pendapatan terhadap tingkat literasi keuangan kepada para pengguna kartu kredit. Jusoh dan Lin (2012) menemukan bahwa terdapat perbedaan yang signifikan antara tingkat pengetahuan keuangan terhadap perilaku penggunaan kartu kredit. Faktor yang berpengaruh signifikan terhadap literasi keuangan di antaranya pengetahuan orang tua, pendapatan, tingkat pendidikan, fakultas, pendapatan orang tua, kepemilikan asuransi (Nidar dan Bestari, 2012). Selain itu, Widayanti (2012) menemukan bahwa pembelajaran di perguruan tinggi mempunyai pengaruh yang signifikan positif secara langsung terhadap tingkat literasi keuangan.

Scheresberg (2013) menemukan bahwa terdapat perbedaan yang kuat tingkat literasi keuangan lakilaki dan perempuan, selain itu terdapat pengaruh yang positif antara tingkat pendidikan dan juga tingkat pendapatan terhadap literasi keuangan, semakin tinggi pendidikan dan pendapatan seseorang maka semakin tinggi tingkat literasi kuangannya. Ebiringa dan Okorafor (2010) menemukan bahwa umur dan lamanya pengalaman bekerja mempunyai pengaruh secara langsung terhadap tingkat literasi keuangan, hal ini dikarenakan semakin bertambahnya umur seseorang maka semakin bertambah pula pengalaman kerjanya sehingga semakin banyak informasi yang diketahui terkait masalah keuangan.

Berdasarkan pertimbangan di atas maka penelitian ini bertujuan untuk menganalisis pengaruh jenis kelamin, usia, tingkat pendidikan dan tingkat pendapatan terhadap tingkat literasi keuangan para pengguna kartu kredit.

\section{TINJAUAN LITERATUR DAN PERUMUSAN HIPOTESIS \\ LITERASI KEUANGAN}

Literasi keuangan merupakan kebu-tuhan dasar bagi setiap orang agar terhindar dari masalah keuangan. Kesulitan keuangan bukan hanya fungsi dari pendapatan semata (rendahnya pendapatan), kesulitan keuangan juga dapat muncul jika terjadi kesalahan dalam pengelolaan keuangan (missmanagement) seperti kesalahan penggunaan kartu kredit dan tidak adanya perencanaan keuangan (Khrisna,et al., 2010). Menurut Lusuardi dan Mitchell (2013) literasi keuangan adalah bagaimana kemampuan seseorang untuk memproses informasi ekonomi yang diperoleh dan membuat keputusan untuk membuat perencanaan keuangan, akumulasi keuangan, pensiun, dan hutang. Menurut Chen dan Volpe (1998) mengartikan literasi keuangan sebagai pengetahuan untuk mengelola keuangan.

Menurut Bushan dan Medhury (2013) Literasi keuangan adalah kemampuan untuk membuat pertimbangan dan membuat keputusan yang efektif terkait dengan manajemen penggunaan uang. Literasi keuangan memungkinkan seseorang untuk memperbaiki keseluruhan kesejahteraannya. Literasi keuangan menolong seseorang untuk memperbaiki level pemahaman seseorang untuk menghadapi masalah keuangan yang memungkinkan untuk mengolah informasi keuangan lalu membuat keputusan yang tepat untuk keuangan pribadi. Literasi keuangan secara langsung berpengaruh terhadap kesejahteraan seseorang. Dalam berbagai penelitian terdahulu ditemukan bahwa seseorang yang mempunyai literasi keuangan yang rendah, menghadapi berbagai permasalahan terkait keuangan pribadi seperti tabungan, pinjaman, investasi, rencana pensiun, dan seterusnya. Dari The social research centre (2011), literasi keuangan adalah kemampuan untuk membuat pertimbangan yang benar untuk mengambil keputusan yang efektif terkait dengan menajemen penggunaan keuangan. Maka dari itu literasi keuangan adalah kombinasi dari keahlian individu, pengetahuan, sikap, dan paling penting 
adalah perilaku mereka yang terkait dengan uang.

Memiliki literasi keuangan merupakan hal vital untuk mendapatkan kehidupan yang sejahtera, berkualitas. Lebih lanjut dijelaskan bahwa literasi keuangan bersama-sama dengan kemampuan membaca dan matematik merupakan kunci untuk dapat menjadi konsumen yang cerdas, mengelola kredit dan mendanai pendidikan yang tinggi. Literasi keuangan sangat penting untuk beberapa alasan penting berikut. Konsumen yang memahami literasi keuangan akan mampu berlayar melalui waktu keuangan yang buruk karena adanya fakta kemungkinan mereka mempunyai tabungan yang terakumulasi, pembelian asuransi, dan diversifikasi investasinya. Literasi keuangan juga secara langsung berkorelasi dengan perilaku keuangan yang positif seperti tepat waktu dalam pembayaran tagihan dan bon serta pinjaman, menabung sebelum menghabiskan dan menggunakan kartu kredit secara bijaksana.

Literasi keuangan merupakan kebu-tuhan dasar setiap orang agar terhindar dari masalah keuangan. Kesulitan keuangan bukan hanya fungsi dari pendapatan semata (rendahnya pendapatan), kesulitan keuangan juga muncul jika terjadi kesalahan dalam pengelolaan keuangan seperti kesalahan penggunaan kredit, dan tidak adanya perencanaan keuangan. Memiliki literasi keuangan merupakan hal vital untuk mendapatkan kehidupan yang sejahtera. Dengan pengelolaan keuangan yang tepat yang tentunya ditunjang oleh literasi keuangan yang baik, maka taraf kehidupan diharapkan dapat meningkat, hal ini berlaku untuk setiap tingkat penghasilan, karena bagaimanapun tingginya tingkat penghasilan tanpa pengelolaan yang tepat, maka keamanan keuangan tentu akan sulit dicapai (Mendari dan Kewal, 2013) .

\section{ASPEK-ASPEK DALAM LITERASI KEUANGAN}

Literasi keuangan mencakup banyak aspek yang perlu diukur. Chen dan Volpe (1998) membagi literasi keuangan menjadi empat aspek, yaitu, pertama adalah pengetahuan tentang keuangan pribadi secara umum (general personal finance Knowledge) meliputi pemahaman beberapa hal yang berkaitan dengan pengetahuan dasar tentang keuangan pribadi. Kedua tabungan dan pinjaman (savings and borrowings) pada bagian ini meliputi pengetahuan yang berkaitan dengan tabungan dan pinjaman seperti penggunaan kartu kredit. Yang ketiga asuransi (insurance) yang meliputi pengetahuan dasar asuransi dan produk-produk asuransi seperti asuransi jiwa, asuransi kendaraan bermotor. Keempat investasi (investment) meliputi pengetahuan tentang suku bunga pasar, reksadana, resiko investasi.

Dalam The Social Research Centre (2011), Perilaku yang terkait dengan uang dapat menjadi indikator literasi keuangan seseorang. Dalam analisis ini ditemukaan 5 perilaku yang menjadi indikator diantaranya: (1) Menjaga catatan keuangan, misalnya selalu memantau saldo rekening dan pengeluaran rumah tangga. (2) Perencanaan masa depan, termasuk perilaku seperti merencanakan pendapatan saat masa pensiun, menggunakan konsultan keuangan, peng-gunaaan asuransi. (3) Memilih produk keuangan, misalnya memperluas penge-tahuan produk keuangan dan jasa keuangan untuk berbelanja. (4) Staying informed (selalu terdepan terhadap perkembangan informasi), misalnya orang-orang yang menggunakan informasi keuangan untuk membuat keputusan. (5) Pengawasan keuangan termasuk hal-hal seperti pengendalian situasi keuangan yang umum dan hutang dan kemampuan untuk menabung.

Kelompok yang mempunyai literasi keuangan yang rendah menurut The Social Research Centre (2011), yaitu: (1) Seorang anak muda yang biasanya usianya kurang dari 25 tahun, (2) Individu yang tidak mendapatkan pendidikan formal sampai 
tingkat SMP, (3) Individu yang mempunyai pendapatan relatif rendah dan asset yang sedikit, (4) Mereka yang bekerja sebagai staff atau bawahan, (5) Perempuan.

\section{KATEGORI LITERASI KEUANGAN PERSONAL}

Personal financial finance adalah sebuah proses mengatur keuangan anda untuk mencapai kepuasan ekonomi anda sendiri (Kapor et al., 2012). Aktivitas keuangan pribadi terdiri atas tiga hal yaitu: (1) Spend (pengeluaran) diantaranya : Biaya kehidupan sehari-hari, pengeluaran utama, kegiatan rekreasi. (2) Save (tabungan) untuk keamanan keuangan dalam jangka panjang. (3) Share (berbagi) untuk memberikan dukungan kepada yang membutuhkan baik secara lokal atau global.

Keuangan pribadi (personal finance) adalah sebuah proses perencanaan pengeluaran, pembiayaan, dan investasi untuk memaksimalkan situasi keuangan anda (Madura, 2011). Sedangkan personal financial plan adalah sebuah perencanaan yang spesifik pada tujuan keuangan anda dan mendeskripsikan pengeluaran, pembiayaan dan rencana investasi yang bertujuan untuk mencapai tujuan anda.

Chen dan Volpe (1998) mengategorikan personal financial literacy menjadi tiga kelompok, yaitu (1) $<60 \%$ yang berarti individu memiliki pengetahuan tentang keuangan yang rendah, (2) $60 \%-79 \%$, yang berarti individu memiliki pengetahuan tentang keuangan yang sedang, dan (3) $>80 \%$ yang menunjukan bahwa individu memiliki pengetahuan keuangan yang tinggi. Pengkategorian ini didasarkan pada persentase jawaban responden yang benar dari sejumlah pertanyaan yang digunakan untuk mengukur personal financial literacy.

The Social Research Centre (2011), faktor-faktor yang menjelaskan perbedaaan tingkat literasi keuangan diantaranya: (1) Umur, terdapat pengaruh yang positif antara umur dengan perilaku yang menjadi indikator literasi keuangan pada group umur 25-34 sedangkan pada kelompok usia 18-24 tidak terdapat pengaruh. Hal ini sesuai dengan semakin banyak pengetahuan mengenai produk keuangan dan juga transaksi keuangan yang digunakan untuk kebutuhan dalam hidup mereka; (2) Pengetahuan keuangan dan kemampuan dalam matematika, terdapat pengaruh yang positif perilaku yang memiliki literasi keuangan dapat mengontrol keuangannya. Hal ini menunjukkan bahwa dengan mempunyai pengetahuan yang baik tentang masalah keuangan yang umum dan juga pengetahuan matematika sangat penting, hal ini dapat digunakan untuk memilih produk keuangan, memantau keuangan (pengeluaran dan pemasukan), dan selalu mempunyai informasi terkini tentang perkembangan keuangan; (3) Financial Attitude (perilaku keuangan), Perilaku keuangan memiliki hubungan (positif maupun negatif) dengan indikator perilaku keuangan; (4) Household income (pendapatan keluarga), Pendapatan keluarga mempunyai hubungan yang relatif kuat dan positif terhadap pengendalian keuangan, hal ini berarti semakin tinggi pendapatan keluarga maka semakin baik pengendalian keuangan; (5) Pendidikan dan pekerjaan, Pendidikan dan pekerjaan mempunyai hubungan dengan beberapa perilaku yang terkait dengan indikator literasi keuangan, karena hal ini menyarankan pada hal-hal penting dibeberapa bagian tapi tidak yang lainnya. Dengan menyelesaikan pendidikan formal tingkat lanjutan (SMA) mepunyai hubungan yang sangat kuat dengan memilih produk keuangan dan tetap bisa terinformasi tetapi tidak akan muncul kepentingan untuk mencatat semua transaksi keuangan, perencanaan ke depan dan juga pengawasan keuangan.

Dalam penelitian yang dilakukan oleh Bushan 
dan Medhury (2013) ditemukan bahwa tingkat literasi keuangan dipengaruhi oleh jenis kelamin, tingkat pendidikan, pendapatan, sifat pekerjaan atau jabatan (nature of employment), dan lingkungan kerja, sedangkan literasi keuangan tidak dipengaruhi oleh wilayah geografi dan juga usia. Selain itu ditemukan bahwa tidak ada perbedaan antara literasi keuangan laki-laki dan perempuan, tidak ada pengaruh antara jenis kelamin terhadap literasi keuangan.

Ibrahim dan Alqaydi (2013) menemukan bahwa tidak ada perbedaan yang signifikan antara literasi keuangan laki-laki dan perempuan, selain itu juga ditemukan bahwa individu yang mempunyai perilaku keuangan yang tinggi (baik) cenderung sedikit dalam penggunaan kartu kredit.

Widayati (2012) menemukan: (1) status sosial ekonomi orang tua berpengaruh langsung positif signifikan terhadap pendidikan pengelolaan keuangan keluarga, (2) status sosial ekonomi orang tua tidak berpengaruh langsung terhadap literasi finansial aspek kognitif, (3) status sosial ekonomi orang tua tidak berpengaruh langsung terhadap literasi finansial aspek sikap, (4) pendidikan pengelolaan keuangan keluarga berpengaruh langsung positif signifikan terhadap literasi finansial aspek kognitif, (5) pendidikan pengelolaan keuangan keluarga berpengaruh langsung positif signifikan terhadap literasi finansial aspek sikap, (6) pembelajaran di perguruan tinggi berpengaruh langsung positif signifikan terhadap literasi finansial aspek kognitif, (7) pembelajaran di perguruan tinggi berpengaruh langsung positif signifikan terhadap literasi finansial aspek sikap, (8) status sosial ekonomi orang tua berpengaruh tidak langsung positif signifikan terhadap literasi finansial aspek kognitif yang dimediasi oleh pendidikan pengelolaan keuangan keluarga, (9) status sosial ekonomi orang tua berpengaruh tidak langsung positif signifikan terhadap literasi finansial aspek sikap yang dimediasi oleh pendidikan pengelolaan keuangan keluarga.

Chen dan Volpe (2002) menemukan bahwa mahasiswi mempunyai pengetahuan yang lebih sedikit tentang keuangan dibandingkan dengan mahasiswa. Selain itu mereka juga menemukan bahwa pendidikan dan pengalaman kerja juga mempunyai pengaruh yang signifikan terhadap literasi keuangan baik laki-laki atau perempuan. Mereka juga membuat observasi yang hasilnya bahwa perempuan biasanya kurang tertarik dan tidak antusias untuk mempelajari hal-hal yang terkait dengan keuangan pribadi dibandingkan dengan laki-laki.

Ludlum et al. (2012) menemukan bahwa beberapa faktor demografi menunjukkan hasil hubungan yang signifikan terhadap literasi keuangan. Mahasiswa yang mempunyai saham menunjukkan secara signifikan lebih mengetahui tentang biaya kartu kredit. Mahasiswa yang menjadi pemegang saham lebih memahami tentang bunga, biaya keterlambatan pembayaran, dan denda karena overlimit. Mahasiswa yang bekerja juga mempunyai pengetahuan yang lebih baik terhadap berita tentang kartu kredit. Mahasiswa yang bekerja lebih bertanggung jawab dan lebih paham pada besarnya suku bunga yang mereka bayar, denda keterlambatan yang mereka bayar, dan denda overlimit yang mereka bayarkan. Status pemahaman tentang kartu kredit. Individu yang menikah mempunyai pengetahuan yang lebih banyak terkait dengan informasi tentang kredit, seperti suku bunga, denda keterlambatan, dan biaya jika melebihi plafon kredit. Individu yang sudah menikah, kebanyakan menjadi mandiri untuk pertama kalinya, hal ini membuat mereka lebih perhatian terhadap permasalahan keuangan yang secara langsung mem-pengaruhi mereka. Jadi menikah mempunyai pengaruh terhadap literasi keuangan, namun tidak demikian dengan 
mempunyai anak. Pasangan yang sudah memiliki anak secara signifikan tidak mempunyai pengetahuan yang lebih baik terkait dengan kartu kredit dibandingkan dengan yang belum mempunyai. Dan jenis kelamin tidak memiliki perbedaan yang signifikan terhadap literasi keuangan.

Luzuardi dan Mitchell (2011) menyatakan bahwa dari berbagai Negara menunjukkan bahwa individu yang dewasa mempunyai pengetahuan yang lebih baik terkait literasi keuangan, setidaknya pengetahuannya di atas rata-rata. Selain itu pola umum lainnya yang jelas: perempuan memiliki literasi keuangan yang lebih rendah dibandingkan dengan laki-laki. Selain itu terdapat perbedaan tingkat literasi keuangan dilihat dari sisi etnik dan ras dan juga regional; sebagai contoh penduduk kota di Rusia lebih memiliki informasi yang jelas dibandingkan dengan penduduk desa, sedangkan di US, penduduk kulit hitam dari Afrika dan Hispanik (orang Spanyol yang tinggal di Amerika) memiliki literasi keuangan yang lebih rendah dibandingkan dengan yang lainnya. Untuk selanjutnya orang yang mempunyai literasi keuangan yang lebih baik maka paling suka untuk membuat perencanaan untuk pensiun.

Ebiringa dan Orokafor (2010) meyakinkan bahwa mahasiswi mempunyai keputusan yang lebih baik terkait dengan keuangan dibandingkan dengan mahasiswa. Setelah dilakukan pengujian ditemukan bahwa jenis kelamin mempunyai hubungan yang terbalik dengan tingkat literasi keuangan adalah prediksi yang tidak signifikan dari tingkat literasi keuangan, berarti tidak ada bukti yang valid untuk membenarkan pernyataan bahwa mahasiswi mempunyai keputusan yang lebih baik terkait dengan keuangan dibandingkan dengan mahasiswa. Selain itu usia dan lamanya pengalaman kerja mempunyai pengaruh secara langsung terhadap tingkat literasi keuangan, hal ini menunjukkan bahwa semakin dewasa dan semakin lama pengalaman bekerja seseorang maka semakin tinggi tingkat literasi keuangan yang dimilikinya.

Nidar dan Bestari (2012) menemukan bahwa tingkat literasi keuangan pribadi mahasiswa/i tergolong dalam tingkat rendah, oleh karena itu harus diperbaiki lagi, terutama dalam hal; investasi, kredit dan asuransi. Tingkat pendidikan, fakultas, pendapatan pribadi, pengetahuan dari orang tua, pendapatan orang tua, dan kepemilikan asuransi mempunyai pengaruh yang signifikan terhadap tingkat literasi keuangan pribadi untuk mahasiswa/

\section{HUBUNGAN LITERASI KEUANGAN DAN GENDER}

Menurut penelitian yang dilakukan oleh Chen dan Volpe (2002) terdapat perbedaan yang signifikan antara laki-laki dan perempuan dalam tingkat literasi keuangan. Mendukung penelitian Chen dan Volpe, penelitian yang dilakukan oleh Sceresberg (2013) terdapat perbedaan yang kuat antara tingkat literasi keuangan laki-laki dan perempuan. Sedangkan dalam penelitian yang dilakukan oleh Khrisna et al. (2010) Menemukan bahwa pria mempunyai literasi keuangan yang lebih rendah dibandingkan dengan wanita. Berdasarkan argumen tersebut maka hipotesis yang dirumuskan adalah:

$H_{1}$ : Terdapat perbedaan yang signifikan tingkat literasi keuangan antara laki-laki dan perempuan.

\section{HUBUNGAN LITERASI KEUANGAN DAN USIA}

Eribinga dan Orokafor (2010) menyatakan bahwa usia mempunyai korelasi langsung terhadap literasi keuangan, semakin bertambah umur dan pengalaman kerja semakin banyak informasi yang diperoleh terkait dengan masalah keuangan The Social Research Centre (2011) menemukan bahwa terdapat hubungan antara usia dengan tingkat literasi keuangan. Berdasarkan argumen tersebut maka hipotesis yang dirumuskan adalah: 
$\mathrm{H}_{2}$ : Terdapat pengaruh yang signifikan antara usia terhadap tingkat literasi keuangan.

\section{HUBUNGAN NILAI LITERASI KEUANGAN DAN TINGKAT PENDIDIKAN}

Tingkat pendidikan merupakan hal yang penting untuk memprediksi tingkat literasi keuangan. Scheresberg (2013) mene-mukan bahwa tingkat literasi keuangan berbeda antara lulusan pasca sarjana, sarjana, atau yang hanya setingkat SMA. Menurut Nidar dan Bestari (2012) tingkat pendidikan mempunyai pengaruh terhadap literasi keuangan. Berdasarkan argumen tersebut maka hipotesis yang dirumuskan adalah:

$\mathrm{H}_{3}$ : Terdapat pengaruh yang signifikan antara tingkat pendidikan terhadap tingkat nilai literasi keuangan.

\section{HUBUNGAN NILAI LITERASI KEUANGAN DAN PENDAPATAN}

Literasi keuangan meningkat seiring dengan peningkatan pendapatan (Scheresberg, 2013). Menurut hasil penelitian Nidar dan Bestari (2012) tingkat pendapatan bulanan berpengaruh terhadap literasi keuangan. Berdasarkan argumen tersebut maka hipotesis yang dirumuskan adalah:

$\mathrm{H}_{4}$ : Terdapat pengaruh yang signifikan antara tingkat pendapatan terhadap nilai literasi keuangan.

\section{METODE PENELITIAN}

\section{METODE PENGUMPULAN DATA DAN SAMPEL}

Data yang digunakan dalam peneli-tian ini adalah data primer yang dipero-leh dari kuisioner yang akan disebarkan ke responden yang memenuhi syarat yaitu responden yang mempunyai penghasilan dan juga menggunakan kartu kredit.

Responden dalam penelitian ini adalah seseorang yang sudah mempunyai penghasilan dan mempunyai kartu kredit di Jakarta dan sekitarnya. Kuisioner disebarkan kepada sebanyak-banyaknya responden, tetapi sebelum menyebarkan kuisioner ke responden maka dilakukan pre-test kepada 10 responden untuk mendapatkan respon serta kritik dan saran terkait dengan kuisioner yang kita ajukan. Jika kuisioner sudah dapat dimengerti oleh para responden selanjutnya akan disebarkan ke responden yang terpilih sebagai sampel.

Teknik pengambilan sampel dalam penelitian ini menggunakan metode purposive sampling yaitu dalam pengambilan sampel terkait dengan pertimbangan-pertimbangan tertentu, sampel yang digunakan hanya yang memenuhi kriteria penelitian. Kuisioner disebarkan dengan 2 metode yaitu: online dan offline, online dilakukan dengan cara menyebarkan link kuisioner yang sudah dibuat menggunakan googledocs adapun link kuisioner online adalah http://bit.ly/AnalisisKeuangan sedangkan secara offline dengan cara menyebarkan kuisioner hard copy ke responden.

\section{DEFINISI OPERASIONAL DAN INSTRUMEN PENGUKURAN VARIABEL}

\section{Variabel Terikat (Dependent Variable)}

Dalam penelitian ini variabel terikatnya adalah literasi keuangan, yakni kemampuan seseorang untuk mengelola keuangannya. Untuk mengukur variabel literasi keuangan maka akan disebarkan kuisioner yang berisi pertanyaan yang terkait dengan literasi keuangan.

\section{Variabel Bebas (Independent Variable)}

Variable bebas yang di gunakan dalam penelitian ini yaitu: (1) Jenis kelamin yangmana variabel ini menjelaskan jenis kelamin responden yaitu laki-laki dan perempuan; (2) Usia, variabel usia untuk menjelaskan usia dari para responden pada saat mengisi kuisioner, dalam penelitian ini diklasifikasikan dalam 3 kelas karena penelitian ini hanya untuk responden yang mempunyai penghasilan maka klasifikasi sebagai berikut: $<30$ tahun, 30 tahun - 40 tahun, lebih dari 40 tahun; 
(3) Tingkat Pendidikan, variabel ini menjelaskan tingkat pendidikan terakhir para responden, yang kemudian diklasifikasikan dalam: SMA, D3, S1, S2, S3; dan (4) Tingkat Pendapatan, Variabel tingkat pendapatan menjelaskan rata-rata besarnya pendapatan bulanan para responden, yang kemudian diklasifikasikan dalam 3 kelompok yaitu : < 10 juta, 10 juta -30 juta, $>30$ juta.

\section{METODE ANALISIS DATA}

Untuk mengukur tingkat literasi keuangan para pengguna kartu kredit maka kuisioner yang berisi 30 pertanyaan yang berhubungan dengan literasi keuangan diantaranya pengetahuan tentang perhitungan keuangan, tabungan, investasi, resiko, dan imbal hasil. Setelah itu jawaban yang benar akan diberi nilai 1 dan yang salah diberi nilai 0 . Kemudian jumlah jawaban yang benar akan dibuat persentase dari jumlah total pertanyaan. Pengujian hipotesis menggunakan ANOVA dengan menggunakan aplikasi SPSS 20. Selanjutnya uji hipotesis akan diuji pada tingkat signifikansi 5\%. Setelah data terkumpul maka kemudian dianalisis dengan menggunakan analisis statistik deskriptif, uji individu (t-test), uji validitas, reliabilitas, dan uji hipotesis dengan menggunakan ANOVA.

\section{HASIL DAN PEMBAHASAN}

UJ VALIDITAS

Uji validitas dilakukan untuk mengetahui tingkat kevalidan dari instrumen (kuisioner) yang digunakan dalam pengumpulan data yang diperoleh dengan cara mengkorelasi setiap skor variabel jawaban responden dengan total skor masingmasing variabel, kemudian hasil korelasi dibandingkan dengan nilai kritis pada taraf signifikansi 0,05 dan 0,01 . Tinggi rendahnya validitas instrumen akan menunjukkan sejauh mana data yang terkumpul tidak menyimpang dari gambaran yang dimaksud Riskawati (2013). Dalam penelitian ini menggunakan tingkat signifikansi 0,05.

Berdasarkan analisis data pada tabel di atas seluruh instrument (pertanyaan/ kuisioner) yang diuji validitas terdapat 1 (satu) pertanyaan yang tidak valid dengan nilai koefisien korelasi 0.095 atau sig. $0.160>0.05$. Sedangkan yang lain 29 pertanyaan dinyatakan valid karena koefisien korelasi lebih besar dari 0.138 ( $r$ tabel) atau p-value lebih kecil dari 0.05.

Berdasarkan hasil pengujian reliabilitas pada tabel di atas dengan melihat koefisien Cronbach's Alpha, instrument/kuisioner yang digunakan dalam penelitian memenuhi kriteria reliabilitas. Hal ini dikarenakan memiliki koefisien Cronbach's Alpha 0.687 lebih besar dari 0.6, maka jawaban responden terhadap pertanyaan-pertanyaan yang digunakan untuk mengukur masing-masing variabel konsisten dan dapat dipercaya.

TABEL 1. UJ RELIABILITAS

\begin{tabular}{llll}
\hline Variabel & Nof ltems & Cronbach's Alpha & Keputusan \\
\hline Literasi keuangan & 30 & 0.687 & Reliabel \\
\hline
\end{tabular}

Statistik deskriptif merupakan gambaran secara singkat mengenai responden dalam penelitian ini. Objek penelitian dalam penelitian ini adalah para pemilik dan pengguna kartu kredit, dimana mereka sudah mempunyai penghasilan atau pendapatan. Jumlah sampel yang diperoleh dalam penelitian ini adalah sebanyak 218 responden, metode pengambilan digunakan metode purposive sampling. Dari keseluruhan data yang diperoleh semua data dapat digunakan dalam penelitian ini. Sampel dikumpulkan dalam jangka waktu 3 minggu pada tanggal 17 November 2014 sampai dengan 08 Desember 2014.

Berdasarkan pengolahan data primer yang diperoleh dari 218 responden yaitu para pengguna kartu kredit, maka diperoleh gambaran tingkat 
TABEL 2. STATISTIF DESKRIPTIF BERDASARKAN DEMOGRAFI

\begin{tabular}{lll}
\hline Variabel & $\begin{array}{l}\text { Jumlah } \\
\text { Responden }\end{array}$ & Presentase \\
\hline Jenis Kelamin & & \\
1. Laki Laki & 96 & $44.0 \%$ \\
2. Perempuan & 122 & $56.0 \%$ \\
Jumlah & 218 & $100.0 \%$ \\
Usia & & \\
1. < 30 Tahun & 103 & $47.2 \%$ \\
2. 30-40 Tahun & 55 & $25.2 \%$ \\
3. > 40 Tahun & 60 & $27.5 \%$ \\
Jumlah & 218 & $100.0 \%$ \\
Tingkat Pendidikan & & \\
1. SMA & 8 & $3.7 \%$ \\
2. D3 & 8 & $3.7 \%$ \\
3. S1 & 115 & $52.8 \%$ \\
4. S2 & 72 & $33.0 \%$ \\
5. S3 & 15 & $6.9 \%$ \\
Jumlah & 218 & $100.0 \%$ \\
Status Pernikahan & & \\
1. Lajang & & \\
2. Menikah & 102 & $46.8 \%$ \\
3. Janda/Duda & 108 & $49.5 \%$ \\
Jumlah & 8 & $3.7 \%$ \\
Tingkat Pendapatan & 218 & $100.0 \%$ \\
1. < Rp $10.000 .000 / B l n$ & 132 & $60.6 \%$ \\
2. Rp10.000.000-Rp30.000.000/Bln & 68 & $31.2 \%$ \\
3. > Rp30.000.000/Bln & 18 & $8.3 \%$ \\
Jumlah & 218 & $100.0 \%$ \\
Jumlah Kartu Kredit & & \\
1. 1 Kartu & & \\
2. 2 Kartu & 112 & $51.4 \%$ \\
3. 3 KartuPerbankan & 58 & $26.6 \%$ \\
4. > 3 Kartu \\
Jumlah & 26 & $11.9 \%$ \\
\hline & 22 & $10.0 \%$ \\
\hline & 218 & $100.0 \%$ \\
\hline
\end{tabular}

TABEL 3. STATISTIK DESKRIPTIF UNTUK TINGKAT LITERASI KEUANGAN (\%)

Statistik Deskriptif Literasi Keuangan

\begin{tabular}{ll}
\hline Minimum & 20.69 \\
Maximum & 96.55 \\
Mean & 59.6172 \\
Standar Deviasi & 14.25570 \\
\hline
\end{tabular}

TABEL 4. KATEGORI TINGKAT LITERASI KEUANGAN

\begin{tabular}{lll}
\hline Katerori & Jumlah & Presentase \\
\hline Rendah & 111 & $50.9 \%$ \\
Sedang & 92 & $42.2 \%$ \\
Tinggi & 15 & $6.9 \%$ \\
Total & 218 & $100.0 \%$
\end{tabular}

literasi keuangan para pengguna kartu kredit. Perhitungan untuk tingkat literasi keuangan dengan cara jawaban responden yang benar lalu dibagi dengan seluruh pertanyaan. Kemudian diperoleh nilai terendah adalah 20.69\% dan nilai tertinggi adalah $96.55 \%$. Hal ini menunjukkan bahwa dari 29 pertanyaan tentang literasi keuangan, ada responden yang hanya bisa menjawab 6 pertanyaan dengan benar (20.69\%) dari 29 pertanyaan yang diajukan, disisi lain ada juga responden yang mampu menjawab 28 pertanyaan dengan benar (96.55\%) dari 29 pertanyaan yang diajukan. Secara keseluruhan atau rata-rata (mean) tingkat literasi keuangan para pengguna kartu kredit masih tergolong rendah < 60 \% yaitu senilai $59,6172 \%$.

Chen dan Volpe (1998) mengate-gorikan personal financial literacy menjadi tiga kelompok, yaitu (1) $<60 \%$ yang berarti individu memiliki pengetahuan tentang keuangan yang rendah, (2) 60\%-79\%, yang berarti individu memiliki pengetahuan tentang keuangan yang sedang, dan (3) > 80\% yang menunjukkan bahwa individu memiliki pengetahuan keuangan yang tinggi. Pengkategorian ini didasarkan pada persentase jawaban responden yang benar dari sejumlah pertanyaan yang digunakan untuk mengukur personal financial literacy.

Berdasarkan Tabel 4 dapat diketahui bahwa 50.9\% atau 111 orang memiliki tingkat literasi keuangan dalam ketegori rendah, 42.2\% atau 92 memiliki tingkat literasi keuangan dalam ketegori sedang dan 6.9\% atau 15 memiliki tingkat literasi keuangan dalam ketegori tinggi.

\section{HASIL UJ HIPOTESIS}

Hasil pengujian hipotesis pertama dengan menggunakan uji-t dua sampel independen dengan kedua variance sama (Equal Variances assumed) yang memberikan nilai p-value (2-tailed) $=0,952>0,05$. Karena nilai p-value $>a ́ a, 05$, sehingga tidak terdapat perbedaan tingkat literasi keuangan laki- 
laki dan perempuan. Hasil penelitian ini didukung oleh penelitian sebelumnya oleh Ebiringa dan Okorafor (2010) yaitu bahwa tidak ada bukti yang mendukung perempuan lebih baik dalam mengambil keputusan keuangan dibandingkan lakilaki. Tetapi hal ini tidak sejalan dengan penelitian yang dilakukan oleh Chen dan Volpe (2002), Sceresberg (2013), dan Khrisna et al. (2010) yang menemukan bahwa terdapat perbedaan yang signifikan antara literasi keuangan laki-laki dan perempuan. Dalam penelitian ini hipotesis pertama tidak dapat diterima karena hanya menggunakan responden dalam jumlah yang kecil yaitu 218, sedangkan dalam penelitian yang terbukti adanya pengaruh jenis kelamin terhadap literasi keuangan menggunakan responden yang banyak. Selain itu responden dalam penelitian ini sangat beragam yaitu mulai dari yang pendidikan SMA hingga S3 dari berbagai tingkat usia sehingga mungkin tidak bisa menggambarkan bahwa literasi keuangan dipengaruhi oleh jenis kelamin sedangkan dalam penelitian Chen dan Volpe (2002), Sceresberg (2013), dan Khrisna et al. (2010) responden yang diambil adalah mahasiswa dan juga anak muda.

Hasil pengujian hipotesis kedua ditemukan nilai p-value $0,004<0,05$ sehingga disimpulkan bahwa terdapat pengaruh yang signifikan antara usia terhadap tingkat literasi keuangan. Hasil penelitian ini sesuai dengan penelitian Eribinga dan Orokafor (2010) menyatakan bahwa usia mempunyai korelasi langsung terhadap literasi keuangan, semakin bertambah usia maka semakin banyak informasi yang diperoleh terkait dengan masalah keuangan. Maka semakin bertambah dewasa maka literasi keuangan seseorang akan semakin meningkat seiring.

Hasil pengujian hipotesis ketiga ditemukan nilai p-value 0,005 $<0,05$ sehingga disimpulkan bahwa terdapat pengaruh yang signifikan antara tingkat pendidikan terhadap tingkat literasi keuangan para pengguna kartu kredit. Hal ini sejalan dengan penelitian yang dilakukan oleh scheresberg (2013) menemukan bahwa tingkat literasi keuangan berbeda antara lulusan pasca sarjana, sarjana, atau yang hanya setingkat SMA. Jadi semakin tinggi pendidikan yang ditempuh maka literasi keuangan semakin tinggi. Menurut penelitian yang dilakukan oleh Nidar dan Bestari (2012) tingkat pendidikan mempunyai pengaruh terhadap literasi keuangan. Hal ini menunjukkan bahwa semakin tinggi pendidikan seseorang maka akan semakin baik literasi keuangannya.

Hasil pengujian hipotesis ketiga ditemukan nilai p-value $0,015<0,05$ sehingga disimpulkan bahwa terdapat pengaruh yang signifikan antara tingkat pendapatan terhadap tingkat literasi keuangan para pengguna kartu kredit. Hal ini menguatkan penelitian yang dilakukan oleh Scheresberg (2013) bahwa literasi keuangan meningkat seiring dengan peningkatan pendapatan. Semakin tinggi pendapatan maka semakin tinggi literasi keuangannya. Menurut Nidar dan Bestari (2012) tingkat pendapatan bulanan berpengaruh terhadap literasi keuangan. Maka semakin tinggi pendapatan seseorang maka tingkat literasi keuangannya juga akan meningkat.

\section{SIMPULAN}

Dari hasil uji ANOVA ditemukan tingkat literasi keuangan para pengguna kartu kredit secara keseluruhan (rata-rata) adalah sebesar 59, $6172 \%$ berarti termasuk dalam kategori rendah karena < $60 \%$. Nilai tersebut diperoleh dari jumlah jawaban benar yang dijawab oleh responden. Dari sisi isu gender yang dikaitkan dengan literasi keuangan, pada penelitian ini ditemukan tidak terdapat perbedaan tingkat literasi keuangan antara laki-laki dan perempuan. Ditemukan pula pengaruh yang signifikan antara usia, tingkat pendidikan, dan pendapatan terhadap tingkat literasi keuangan. 
Implikasi dari hasil penelitian ini adalah sebaiknya masyarakat, khususnya para pengguna kartu kredit, mempelajari hal-hal yang terkait dengan keuangan pribadi dan literasi keuangan. Dengan literasi keuangan yang lebih baik maka seseorang akan mencapai kesejahteraan keuangan, kehidupan yang lebih berkualitas dan dapat mencapai kebebasan keuangan dimasa mendatang dengan mengatur keuangan secara baik dan benar. Karena dengan mempunyai literasi keuangan yang baik maka akan mempunyai informasi yang benar terkait dengan langkah-langkah yang harus diambil. Dengan informasi yang benar maka dapat membuat keputusan yang tepat terkait dengan jasa keuangan apa yang digunakan, pilihan pinjaman kredit, dan perencanaan masa tua yang lebih baik, serta membuat diversifikasi investasi. Bagi pemerintah, dengan penelitian ini diharapkan agar pemerintah lebih fokus untuk membuat program pendidikan yang dapat meningkatkan literasi keuangan masyarakat misalnya yang sudah dilakukan melalui OJK. Program-program pelatihan yang terkait dengan pengelolaan keuangan harus lebih merata ke suluruh Indonesia. Karena dalam penelitian ini terbukti bahwa pendidikan mempunyai pengaruh yang signifikan terhadap tingkat literasi keuangan maka pemerintah juga diharapkan fokus untuk memeratakan dan meningkatkan kualitas pendidikan di Indonesia. Hal ini dikarenakan dengan literasi keuangan yang baik maka masyarakat akan semakin sejahtera karena mampu mengelola asset dengan benar, bahkan dengan literasi keuangan yang baik masyarakat akan lebih termotivasi untuk melakukan investasi dengan peningkatan investasi maka produktivitas akan meningkat pula yang akan meningkatkan pertumbuhan ekonomi.

Selain itu, bagi lembaga pendidikan, khususnya universitas, diharapkan dapat memberikan pelajaran yang dapat meningkatkan literasi keuangan mahasiswa, pelajaran tentang keuangan pribadi. Walaupun terbukti dalam penelitian ini bahwa pendidikan mempengaruhi tingkat literasi keuangan, yang berarti individu yang menempuh pendidikan di universitas akan mempunyai literasi keuangan yang lebih baik dibandingkan dengan yang lulus SMA. Tetapi hasil penelitian ini juga menunjukkan rendahnya tingkat literasi para pengguna kartu kredit yaitu sebesar 59,62\%, dengan responden terbanyak adalah lulusan S1 yaitu 52,8\%. Hal ini bisa disimpulkan bahwa literasi individu yang menempuh pendidikan diperguruan tinggi juga masih rendah. Maka sangat diperlukan untuk memberikan pelatihan atau memberikan kursus terkait dengn literasi keuangan atau lebih baik jika literasi keuangan menjadi mata kuliah wajib bagi mahasiswa agar mahasiswa menjadi insan yang cerdas dan mampu membuat keputusan yang terkait dengan keuangannya dengan tepat supaya mencapai kesejahteraan keuangan yang lebih baik di masa depan. Karena mahasiswa nantinya akan menjadi pelaku ekonomi setelah mereka lulus, maka mempunyai literasi keuangan yang baik akan membantu mereka untuk mengalokasikan penghasilannya dengan benar untuk mempersiapkan hari tua.

Terakhir, bagi penerbit kartu kredit, Sebaiknya para penerbit kartu kredit tidak fokus pada penambahan jumlah konsumen saja tetapi juga fokus pada memberi pembelajaran terkait dengan literasi keuangan dan juga manajemen keuangan pribadi. Selain itu diharapkan lembaga keuangan lebih teliti dalam merekrut staf pemasaran kartu kredit, karena banyak staf pemasaran yang hanya mengejar targetnya tanpa mempertimbangkan apakah konsumen yang diberikan kartu kredit mempunyai kapabilitas. Lembaga keuangan sebaiknya lebih peduli untuk memberikan pelatihan tentang literasi keuangan kepada para staf pemasaran, sehingga mereka akan mampu 
memberikan penjelasan yang baik dan benar kepada konsumen bahkan secara tidak langsung para staf memberikan pem-belajaran terkait literasi keuangan kepada calon konsumen. Pemahaman tentang literasi keuangan dan keuangan pribadi yang baik akan mengurangi adanya kredit gagal bayar, atau menghindari komplain konsu-men yang disebabkan karena konsumen yang kurang paham akan biaya-biaya yang terkandung dalam kartu kredit itu sendiri. Dengan konsumen yang lebih cerdas maka bank juga akan meraih keuntungan yang lebih baik.

\section{DAFTAR PUSTAKA}

Bushan, P. dan M. Yajulu. 2013. Financial Literacy and Its Determinants. International Jounal Or Engeenering, Business And Entreprise Applications, 155-160.

Chen, H., Volpe dan Ronald. P. 1998. An Analysis of Personal Finance Literacy Among College Students. Financial Services Review, 7, 107-128.

Chen, H. Volpe, dan P. Ronald. 2002. "Gender Differences In Personal Financial Literacy Among College Students". Financial Services Review, 11, 289-307.

Disney, R and Gaathergood, J. 2012. Financial Literacy and Consumer Credit Portfolio. Centre for Finance and Credit Markets, 1-31.

Ebiringa, O. T. dan E. O. Okorafor. 2010. Financial Literacy and Financial Decition Making Capacity: The Gender Balance Issue. Jounal of sustainable Development in Africa, 12 (7), 15-32.

Hair, J. F. W. C. Black dan R. E. Anderson. 2010. Multivariate Data Analysis. New Jersey. Edisi ke 7. Pearson Education Inc.

Ibrahim, M., E. Alqaydi dan R. Fatima 2013. Financial Literacy, Personal Financial Attitude, and Forms of Personal Debt among Residents of the UAE. International Journal of Economics and Finance, 5 (7), 126-138.

Jusoh, Z. Md. dan L. L. Yen. 2012. Personal Financial Knowledge and Attitude towards Credit Card Practices among Working Adults in Malaysia. International journals of business and social science, 3 , 176- 185.

Kapoor, D. dan Hughes. 2012. Personal Finance. Edisi 10. Mc Graw Hill.

Khrisna, A. dan R. R. S. Maya. 2010. Analisis Tingkat Literasi Keuangan di Kalangan Mahasiswa dan Faktor-Faktor yang mempengaruhinya. Proceedings of The 4th International Conference on Teacher Education; Join Conference UPI dan UPSI.

Ludlum, M., T. Kris, R. David, C. Tammy, X. Weichu, dan B. C. Smith. 2012. Financial Literacy and Credit Card: A Multy Campus Survey. International Jounal of Business and social science. 9, 32-45.

Luzuardi, A. dan M. Olivia S. 2011. Financial Literasi Around the world: An Overview, National Bureau Of Economic Research. NBER working paper No. 17170, 1-17

Madura, J. 2011. Personal Finance, Edisi 4. NY: Pearson.
Mendari, A.S dan S. S. Kewal. 2013. Tingkat Literasi Keuangan di Kalangan Mahasiswa STIE Musi. Jurnal Economia, 9 (2), 130-140.

Nidar, S. R dan B. Sandi. 2012. Personal Financial Literacy Among University Students (Case Study At Padjajaran University Students, Bandung, Indonesia). World Journal of sciences, 2 (4), 162-171.

Riduwan dan E. A. Kuncoro. 2011. Cara Menggunakan dan Memakai Path Analisis. Bandung: Alfa Beta.

Riduwan dan Sunarto 2009. Pengantar Statistika. Alfa Beta. Bandung

Sceresberg, C. D. B. 2013. Financial Literacy and Financial Behavior among Young Adult: Evidence and Implication. Numeracy Advancing Education in Quantitative Literacy, 6, 1-21.

Shandra, J. H. 2010. Measuring Financial Literacy. The Journal of Consumer Affair, 44 (2), 296-316.

The Social Research Centre. 2011. Adult Financial Literacy In Australia. Executive summary of the 2011 result from ANZ survey.

Uyanto, S. S. 2009. Pedoman Analisis Data dengan SPSS. Yogyakarta: Graha IImu.

Widayanti, I. 2012. Faktor-Faktor Yang Mempengaruhi Literasi Financial Mahasiswa Fakultas Ekonomi Dan Bisnis Universitas Brawijaya. Jurnal Akuntansi Dan Pendidikan, 1 (1) 89-99. 